В.І. Савенко, к.т.Н., д-р будівництва, доцент, КНУБА;

Л.М. Висоцька, директор ПП "Руслан і Людмила";

Д.Я. Кислюк, к.т.н., доцент, ЛНТу;

В.В. Клюєва, асистент, КНУБА;

С.В. Федоренко, к.т.н., доцент, КНУБА;

С.П. Пальчик, аспірант, КНУБА, м. Київ

\title{
ЕКОНОМІЧНА ДОЦІЛЬНІСТЬ ПОДОВЖЕННЯ ТЕРМІНІВ ЕКСПЛУАТАЦЇ̈ МЕТАЛЕВИХ КОНСТРУКЦЙ, МАШИН ТА ВИРОБІВ ШЛЯХОМ ЗАХИСТУ ВІД КОРОЗІї ЕКОЛОГІЧНО ЧИСТИМИ ЗАСОБАМИ (CONTRRUST)
}

\begin{abstract}
Анотація. Корозія приводить до мільярдних збитків щорічно, які полягають у виведенні з ладу виробів $і$ машин з металу, а також у витратах по захисту $i$ відновленню металевих виробів. Дослідження процесів корозї дає основу стверджувати, що надійний захист від корозї - це в першу чергу правильна підготовка поверхні і тільки потім якісний шар герметиків, фарб або іниих типів покриття.

Екологічно чиста речовина рослинного походження, запатентована $і$ випробувана, з назвою "KOHTPACT (CONTRRUST)" є ефективним засобом блокування джерел корозії (іржавіння) $i$ підготовки поверхонь до захисних покриттів.

Ключові слова: КОНТРАСТ, корозія, іржа, захисні покриття, екологія.
\end{abstract}

Постановка проблеми. Величезні затрати на заміну чи відновлення вражених корозією металевих частин, деталей машин і устаткування, конструкцій будівель і виробів широкого вжитку спонукають людство до пошуків засобів захисту від корозії. Дослідження і досвід багаторічної експлуатації металевих виробів показують, що найважливішим моментом у захисті і запобіганні корозії є надійна і правильна підготовка поверхонь металів до пофарбування. Легше і надійніше запобігти процесу корозії, ніж зупинити і відновити вражені деталі і вироби.

Аналіз публікацій. Відомо багато досліджень процесів корозії і улаштування захисних покриттів. Icнує також багато речовин для очистки поверхонь, інгібіторів, напилень, домішок і т.п. Екологічно безпечних, ефективних засобів рослинного походження не представлено. С вже запатентований перетворювач "CONTRRUST" Патент № (11) 61544, автор Висоцька Л.М. Але технологія його застосування i просування на ринку ще іде досить повільно.

Метою роботи $є$ вивчення видів корозії і процесів, що випробуються при початку і в ході кородування металів, для знаходження надійних реагентів погашення мікроджерел корозії і створення надійної плівки (захисного шару) на поверхні до пофарбування, під якою неможливий початок корозії під захисним шаром.

Виклад основного матеріалу. В силу об'єктивних і суб'єктивних причин; недобросовісної конкуренції, некомпетентності, корупції і т.д. на сучасному етапі розвитку виробництва, науки і техніки втрати від корозії в промислово розвинених країнах досягають 3-5\% національного доходу. В Україні проблеми 3 корозією значно більші внаслідок ряду причин. Більшість споруд, які все ще знаходяться в експлуатації, якраз досягли критичного віку 40-60 років. Фахівці вважають, що об'єкти 3 таким терміном служби близькі або знаходяться в передаварійному стані. Особливо це стосується металургійних і хімічних під- приємств, нафто- і газопроводів, плавзасобів, де елементи і конструкції працюють в високоагресивних середовищах. Саме з причини корозії на рік втрачається 1,5 - 2\% з 100 млн. тонн конструкцій, що використовуються. Це приводить до мільярдів доларів збитків, виникнення надзвичайних ситуацій, екологічних катастроф.

Особливий збиток приносить корозія металів. Найпоширеніший і найбільш знайомий усім нам вид корозії - іржавіння заліза. Тому арки мостів ферми, балки та інші конструкції і вироби з металу треба захищати комплексно. Корозія - це фізико-хімічна взаємодія металу з середовищем, що веде до руйнування металу. В результаті корозії метали переходять в стійкі сполуки - оксиди або солі, у вигляді яких вони знаходяться в природі. Корозія з'їдає до 10 відсотків виробленого в країні металу. Важко врахувати непрямі втрати від простоїв і зниження продуктивності устаткування, що піддалося корозії, від порушення нормального ходу технологічних процесів, від аварій, обумовлених зниженням міцності металевих конструкцій.

Іржа - це шар частково гідратованих оксидів заліза, що утворюється на поверхні заліза і деяких його сплавів в результаті корозії.

За механізмом корозія буває хімічна, електрохімічна (процес електрохімічної корозії можна уповільнити не лише шляхом безпосереднього гальмування анодного процесу, але також впливаючи на швидкість катодного. Найбільш поширені два катодних процеси: розряд водневих іонів $\left(2 \mathrm{e}+2 \mathrm{H}^{+}=\mathrm{H} 2_{2}\right)$ i відновлення розчиненого кисню

$4 \mathrm{e}+\mathrm{O}_{2}+4 \mathrm{H}^{+}=2 \mathrm{H}_{2} 2 \mathrm{O}$ або $4 \mathrm{e}+\mathrm{O}_{2}+2 \mathrm{H}_{2} 2 \mathrm{O}=4 \mathrm{OH}$,

які часто називають відповідно водневою і кисневою деполяризацією, газова, атмосферна корозія, рідинна корозія, підземна корозія (характерною особливістю підземної корозії є різниця в швидкості (в десятки тисяч разів) доставки кисню (основного деполяризатора) до поверхні підземних конструкцій у 
різних грунтах).

Сучасний захист металів від корозї базується на таких методах:

- підвищення хімічного опору конструкційних матеріалів,

- ізоляція поверхні металу від агресивного середовища,

- зниження агресивності виробничого середовища,

- зниження корозії накладенням зовнішнього струму (електрохімічний захист).

Ідеальний захист від корозії на 80\% забезпечується правильною підготовкою поверхні і тільки на 20\% якістю лакофарбових матеріалів, що використовуються, і способом їх нанесення.

Тривалість і ефективність покриття по сталевих поверхнях залежать в дуже великій мірі від того, як ретельно підготовлено поверхню для фарбування Підготовка поверхні полягає в попередній підготовці, що має на меті усунення окалини, іржі та сторонніх речовин, якщо вони $\epsilon$, зі сталевої поверхні перед нанесенням заводської грунтовки або праймера. Вторинна підготовка поверхні спрямована на усунення іржі або сторонніх речовин, якщо вони є, зі сталевої поверхні із заводською грунтовкою або праймером до нанесення антикорозійної фарбувальної системи.

За останні роки цій проблемі не тільки не приділяється увага на державному рівні, а й практично припинили своє існування галузеві системи нагляду за експлуатацією будівель і споруд. На теперішній час має місце значне відставання як в організаційному плані, так і за рівнем технологій антикорозійного захисту: у нас немає сформованого напрямку і відпрацьованої обов'язкової системи обстеження об'єктів, правил включення інноваційних технологій в проектно-кошторисну документацію та нормативні документи з метою підвищення корозійної стійкості експлуатованих об'єктів, довгобудів і металопрокату на складах. Жорсткі умови експлуатації металоконструкцій і підвищені вимоги їх технічного стану визначають необхідність застосування надійних, екологічно чистих і економічно вигідних засобів для антикорозійного захисту поверхні виробів та зниження швидкості корозії сталевих конструкцій, що експлуатуються в атмосферних умовах і технологічних середовищах.

Для вирішення проблем корозії металоконструкцій, мінімізації шкоди навколишньому середовищу, здоров'ю людини та стану будівель і споруд, зменшенню трудовитрат, строків ремонту та будівництва об'єктів, досягнення високого економічного ефекту винайдений перетворювач іржі. Перетворювач складається 3 дубильного екстракту, харчової кислоти і води, що містить срібло у складі мас.\%: дубильний екстракт 15,0 - 45,0, харчова кислота 3,0 - 2,0, решта - вода 3 вмістом срібла 0,001-0,05 мг / дм³. Якщо товщина іржі перевищує 300 мкм, краще щоб перетворювач містив 0,001-0,005 мас.\% гептагерманата натрію (Na6GE2O7), він сприяє кращому проникненню перетворювача в раковини металу і служить для знищення центрів корозії (Україна, Патент №61544, C 09 D 5/08 (додаток №1); Азербайджан, Патент №IXTIRA I 20070104 (додаток №2) автор Висоцька Л.М.). Для антикорозійного захисту плавзасобів, а також металоконструкцій, які постійно зна- ходяться в агресивних середовищах до складу перетворювача можливе додавання 10,0-15,0 мас.\% рідкого натрієвого скла $\left(\mathrm{Na}_{2} \mathrm{O}(\mathrm{SiO})_{2}\right)$.

$\mathrm{Y}$ патенті UA 61544 розкритий перетворювач іржі, що містить мінімальну кількість компонентів, але має здатність до нанесення на іржаві поверхні, покриті конденсатом, має високу перетворюючу здатність, малий час висихання, що й забезпечує міцність отриманого покриття й стійкість його до впливу води, масла й нафти-сирцю, бензину й інших середовищ, $з$ якими контактує покриття.

Він має такий склад (мас. \% ):

дубильний екстракт $15,0-45,0$

харчова кислота $3,0-12,0$

вода 3 вмістом срібла 0,001-0,05 мг/дм ${ }^{3}-$ решта.

Додатково перетворювач іржі може містити $0,001-0,005$ мас.\% гептагерманату натрію ($\mathrm{Na}_{6} \mathrm{Ge}_{2} \mathrm{O}_{7}$ ) або 10,0 - 15,0 мас.\% рідкого натрієвого скла.

Описана композиція найбільш пристосована для виконання певної функції: грунту, модифікатора, перетворювача іржі.

В процесі впровадження перетворювача іржі "CONTRRUST" було проведено удосконалення 3 метою досягнення ще вищого економічного ефекту і просування на міжнародні ринки, враховуючи те, що аналога немає.

Матеріал "КОНТРАСТ" відноситься до засобів для боротьби з іржею, а точніше, до композицій для боротьби з іржею на основі таніну.

Танін є природною дубильною речовиною, що утворює з оксидами заліза нерозчинні танат-комплекси. У композиціях для боротьби з іржею як танін використовують дубильні екстракти деревини (дуб, верба, ялина).

В основі нової технології боротьби з корозією лежить універсальний перетворювач іржі, засіб, який:

- має підвищені проникаючу й перетворюючу здатність і має властивості модифікатора;

- забезпечує утворення міцно зчепленої з основою металоконструкції плівки, яка має ефект інгібітору корозії, може служити як консервант і як грунт із підвищеною теплостійкістю й термостабільністю, знижує наводнювання сталі, має фунгіцидні властивості;

- виключає утилізацію відпрацьованих шкідливих для здоров'я й навколишнього середовища матеріалів (оксиди заліза, оксиди кремнію й алюмінію, природний газ, вуглекислий газ), які використовуються при очищенні іржавої поверхні дорогими способами очищення (абразиво-струминний, полум'яний й полум'яно-абразивний, гідробластинг);

- цінною властивістю створеної речовини "КОНТРАСТ" є також можливість створення композиції для приготування перетворювача іржі, яка була б зручна при транспортуванні, зберіганні й приготуванні перетворювача іржі.

Ще одним важливим моментом є розробка способу приготування перетворювача іржі у вигляді концентрату, і це втілено на підприємстві ПП "Руслан і Людмила"

В перетворювачі іржі модифікації "А" ДСТУ №4372:2005 (додаток №4), що включає дубильний 
екстракт, щавлеву кислоту, джерело срібла й воду як джерело срібла використане азотнокисле срібло. Перетворювач додатково містить оксиетилидендифосфонову кислоту-1 і дубильний екстракт.

Дубильні екстракти - це речовини, які екстрагуються парою з дубильної деревини і кори дуба, верби, ялини та ін. В перетворювачі іржі зв'язуючими і пасивуючими іржу є таніни - основний компонент сухої частини дубильних екстрактів. За хімічною будовою таніни - це поліфеноли, будова яких дуже складна.

3 іржею і поверхнею металу таніни взаємодіють своїми гідроксидними групами. Хімізм реакції можливо представити таким чином:

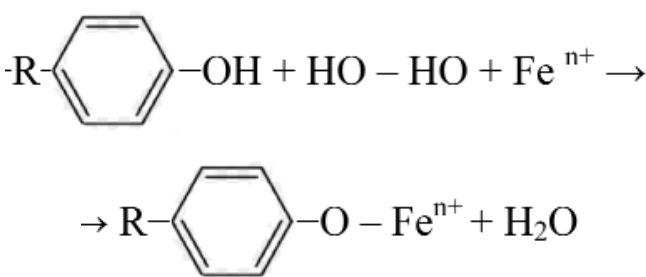

де $\mathrm{Fe}^{\mathrm{n}+}-$ іон заліза наявний в іржі; $\mathrm{n}$ може бути рівним 2 або 3 щавлева кислота 3,80 - 7,72

$\mathrm{H}_{2} \mathrm{C}_{2} \mathrm{O}_{4}-2 \mathrm{H}_{2} \mathrm{O}$ азотнокисле срібло 0,01 - 0,10 $\mathrm{AgNO}_{3}$ оксиетилидендифосфонова кислота 1 $0,15-0,67$

вода або вода зі спиртом решта

Оксиетилидендифосфонова кислота-1(ОЕДФ), будучи розчиненою у воді, має поверхневу активність, тому сприяє швидкому проникненню перетворювача в пори іржі, навіть найдрібніші. ОЕДФ синергетично підсилює перетворюючу здатність танінів. На основі металоконструкції утворюється міцно зчеплена 3 нею танатна плівка, яка має ефект інгібітору корозіі. Плівка знижує наводнювання сталі - небезпечне явище, яке робить сталь крихкою і яке відбувається під впливом на сталь органічних кислот. Плівка служить як грунт із високою теплостійкістю й термостабільністю при наступному нанесенні лакофарбових і ізоляційних покриттів.

Проникаючи в пори окалини, ОЕДФ пасивує велику кількість продуктів корозії, що приводить до відшаровування окалини від прокородованого металу й до виникнення адгезивного контакту між ним i грунтувальним покриттям. Вступаючи в хімічну реакцію з поверхнею металу, утворює плівку. Плівка, що утворилася, має ефект інгібітору, не дозволяє вступати в реакцію активної поверхні заліза з киснем у вологому середовищі. Поверхня стає більш стійкою до корозії:

$$
\begin{array}{cl}
\mathrm{OH} \mathrm{CH}_{3} \mathrm{OH} \\
\mathrm{I}= \\
\mathrm{P}-\mathrm{C}-\mathrm{I}=\mathrm{O} \\
\mathrm{I} \quad \mathrm{I} \quad \mathrm{I} \\
\mathrm{OH} \text { OH } \mathrm{OH}
\end{array}
$$

Наявність у воді азотнокислого срібла в комбінації з ОЕДФ дозволяє досягати глибокої дифузії перетворювача в шар іржі, що сприяє утворенню міцної плівки з високою адгезією. Одержане покриття має високу стійкість до впливу води, масел, нафтисирцю й газів, що утворюються під землею при блукаючих струмах.
Завдяки додаванню азотнокислого срібла поверхня металоконструкції, оброблена перетворювачем, і сам перетворювач не зазнає біокорозії. Особливо ефективне використання азотнокислого срібла при підвищеному вмісті в контактуючій з металоконструкцією воді хлорид іонів, які активізують процеси корозії. Тому, для нейтралізації додається азотнокисле срібло, яке взаємодіє в реакції іонів срібла з іонами хлору $\mathrm{Ag}^{+}+$ $\mathrm{Cl}-=\mathrm{AgCl}$ (іони хлору випадають в осад).

Крім того, азотнокисле срібло не випадає в осад при зберіганні перетворювача іржі, що має місце в перетворювачі іржі за патентом UA 61544, у якому використовується колоїдне срібло.

Триполіфосфат натрію, гексаметафосфат натрію й гліоксаль ще більше підсилюють інгібіторні властивості плівки, що надалі запобігає загальнокорозійному процесу.

Лимонна кислота підсилює консервуючі властивості перетворювача іржі й він може успішно застосовуватися як консервант для запобігання корозії при зберіганні металопрокату й металевих елементів і конструкцій.

В композиції для приготування перетворювача іржі, що включає дубильний екстракт, щавлеву кислоту й срібло, як джерело срібла використане азотнокисле срібло, і вона додатково містить оксиетилидендифосфонову кислоту-1 при такому співвідношенні компонентів, у мас. \% (модифікація "Б" (пастоподібна суміш) ДСТУ 4372:2005) :

дубильний екстракт 49,00 - 76,00

щавлева кислота 23,00 - 47,00

азотнокисле срібло $0,05-0,60$

оксиетилидендифосфонова

кислота-1 0,95 - 4,00.

Краще, щоб композиція містила також такі компоненти, мас.\%

триполіфосфат натрію $0,40-1,30$

гексаметафосфат натрію $0,40-1,30$

гліоксаль 3,10 - 3,45

Композиція може містити також 0,90-3,50 мас. \% лимонної кислоти.

Композиція може містити воду в пропорції: на одну масову частину композиції $0,20-0,50$ масових частин води.

Згідно з винаходом третє завдання вирішується тим, що описану вище композицію змішують із водою в пропорції на одну масову частину композиції 5 6,25 масових частин води. При необхідності $0,10-$ 0,30 мас. \% води замінюють спиртом.

Композиція для приготування перетворювача іржі згідно з винаходом може бути або у вигляді сухої суміші, або у вигляді пастоподібної суміші. Для одержання сухої суміші (модифікація "В" ДСТУ 4372:2005) порошкоподібні компоненти змішують у необхідних кількостях і фасують у паперову або полімерну упаковку. Вагу сухої суміші в упаковці розраховують на певну кількість води, яка необхідна для одержання перетворювача іржі, готового до застосування модифікації "А" рідина.

Готовий перетворювач іржі являє собою рідину коричневого кольору, що має такі характеристики:

$\mathrm{pH} 0,5-2,2$ моль/л

в'язкість за ВЗ при $20 \pm 20 \mathrm{C} 9-12$ сек.

питома вага 1,08 г/ $\mathrm{cm}^{3}$

витрата $40-120$ г на 1 м $^{2}$ 
Перетворювач іржі "КОНТРАСТ" модифікації "А", "Б", "В", починаючи з 2000 року, пройшов успішні випробування і отримав позитивні відгуки від споживачів, має нагороди.

Існує велика кількість різних станів металевих поверхонь, що вимагають очищення перед фарбуванням. Насамперед, це стосується ремонту раніше пофарбованих об'єктів. Вік об'єкта і його розташування, якість вихідної поверхні, властивості старого лакофарбового покриття і кількість дефектів, тип попередніх і майбутніх агресивних умов і передбачувана система захисних покриттів - все це впливає на вибір методів майбутньої підготовки поверхні перед фарбуванням. При виборі методу підготовки поверхні слід враховувати необхідний ступінь очищення і шорсткості поверхні, відповідні системи покриття. Ступінь підготовки поверхні вибирається 3 метою підвищення надійності та якості покриття, зниження вартості робіт.

Металеві поверхні, що підлягають очищенню, класифікують за ступенем окислення за стандартами ISO 8501-01-1988 i ISO 8504-1992. Характеристика окислення поверхні визначається ступенем окислення:

A - поверхня сталі майже повністю покрита міцно зчепленою з металом прокатною окалиною. На поверхні майже немає іржі;

В - поверхня сталі почала іржавіти, від неї починає відшаровуватися прокатна окалина;

C - поверхня сталі, з якої в результаті корозії майже повністю зникла прокатна окалина, або з якої прокатна окалина може бути легко видалена. На поверхні сталі при візуальному огляді спостерігаються невеликі прояви корозії;

$\mathrm{D}$ - поверхня сталі, з якої в результаті корозії прокатна окалина зникла і на якій спостерігається виразкова корозія на всій поверхні при візуальному огляді.

Широко відомий недолік заліза і сталі полягає в тому, що ці матеріали іржавіють, тобто піддаються одній $з$ форм корозії. Для того, щоб продовжити термін служби дорогого устаткування і створити умови для оптимальної віддачі від капіталовкладень, залізні і сталеві частини конструкцій зазвичай піддаються антикорозійній обробці за допомогою нанесення на них одного або декількох захисних шарів фарби та інших матеріалів. При цьому потрібно враховувати стійкість покриттів до впливу сукупності кліматичних факторів, значення яких обумовлені нормальними значеннями на відкритому повітрі різних макрокіматичних районів і категоріями розміщення пофарбованих поверхонь.

Позначення умов експлуатації за ГОСТ 9.10479, макрокліматичних районів за ГОСТ 15150-69: помірний (У1, У2, УХЛ4, В5); холодний (ХЛ1, ХЛ2, УХЛ4, В5); тропічний сухий і тропічний вологий (T1, T2, Т3, В5); морський помірно холодний (OM1, OM2, OM3, B5) і морський тропічний (OM1, OM2, OM3, В5).

Перед нанесенням захисного шару необхідно провести ретельну обробку поверхні з метою отримання найкращого зчеплення фарби з поверхнею.

Існує ряд способів очищення поверхні перед фарбуванням: абразиво-струминне очищення, полум'яне і полум'яно-абразивне очищення, гідробластінг, в яких використовуються дорогі і шкідливі для здоров'я людини та навколишнього середовища матеріали (оксиди кремнію, оксиди алюмінію, окису заліза, природний газ, вуглекислий газ). Поховання відпрацьованих матеріалів приводить до підвищення собівартості робіт в десятки разів.

Одним 3 найбільш ефективних методів підготовки поверхонь є струминне очищення із застосуванням абразивів. Іншими методами попередньої обробки поверхонь є очищення ручне і механічне, термічне очищення та очищення із застосуванням хімічних препаратів (травлення). Останні вищезгадані методи мають різні недоліки, такі як недостатня ступінь чистоти поверхні, нанесення шкоди здоров'ю людини і навколишньому середовищу. Ретельна попередня обробка поверхні дуже важлива. Навіть найкращі методи нанесення захисних покриттів по своїй дії ніколи не перевершують значення якості попередньої обробки поверхні. У більшості випадків причиною передчасного виходу з ладу захисних покриттів $є$ недостатня (або не відповідає вимогам) попередня підготовка поверхонь, осмос та не заблоковані центри корозії в раковинах металу.

Стандарт ISO визначає сім ступенів підготовки поверхні: тами.

- ISO-St Обробка вручну і електроінструмен-

Підготовка поверхні вручну і за допомогою електроінструментів: скріблення, зачистка дротяними щітками, механічними щітками і шліфування - позначається буквами "St".

Перш, ніж почати очищення вручну або електроінструментами, товсті шари іржі мають бути видалені способом обрубки. Видимі забруднення від масла, жиру і бруду теж повинні бути вилучені. Після очищення вручну та електроінструментами поверхня повинна бути очищена від фарби і пилу.

- ISO-St2 Ретельне очищення вручну та електроінструментами.

При поверхневому розгляді неозброєним оком , підкладка повинна виглядати очищеною від видимих слідів масла, жиру і бруду і від погано прилеглої окалини, іржі, фарби та сторонніх речовин.

- ISO-St3 Дуже ретельне очищення вручну та електроінструментами - те ж саме, що і для St2, але підкладка має бути очищена набагато більш ретельно, до появи металевого блиску.

- ISO-Sa Піскоструминне очищення.

Підготовка поверхні способом піскоструминної обробки позначається буквами "Sa". Перш ніж приступити до піскоструминного очищення, товсті шари іржі мають бути видалені методом обрубки. Видимі масляні, жирові забруднення і бруд теж повинні бути усунені. Після піскоструминної обробки підкладка має бути очищена від пилу та сміття.

- ISO-Sa1 Легке піскоструминне очищення.

При перевірці неозброєним оком поверхня повинна виглядати зачищеною від видимих масляних, жирових плям і бруду і від окалини з поганим приляганням, іржі, фарби та інших сторонніх речовин.

- ISO-Sa2 Ретельне піскоструминне очищення.

При перевірці неозброєним оком поверхня повинна виглядати зачищеною від видимих масляних, жирових плям і бруду і від більшої частини окалини, іржі, фарби та інших сторонніх речовин. Кожне залишкове забруднення повинно мати щільне прилягання. 
- ISO-Sa2,5 Дуже ретельне піскоструминне очищення.

При перевірці неозброєним оком поверхня повинна виглядати зачищеною від видимих масляних, жирових плям і бруду і від більшої частини окалини, іржі, фарби та інших сторонніх речовин. Всі залишкові сліди зараження повинні виявлятися тільки у формі ледь помітних плям і смуг.

- ISO-Sa3 Піскоструминне очищення до візуально чистої сталі.

При перевірці неозброєним оком поверхня повинна виглядати зачищеною від видимих масляних, жирових плям і бруду і від більшої частини окалини, іржі, фарби та інших сторонніх речовин. Поверхня повинна мати однорідний металевий блиск.

У відповідності до ГОСТ 9.402-80:

- пункт 3.9.2.6 прим.2: "Кварцовий пісок застосовується тільки при струменево-абразивній обробці";

- пункт 3.9.2.7: "Струменево-абразивну обробку виконують суспензією піску або електрокорунду у воді під тиском 0,3-1,0 МПа (3,0-10,0кгс / см²), об'ємне відношення абразиву до води має становити від 1 : 6 до $1: 1$. ";

- пункт 3.9.2.8: "Для запобігання корозії чорних металів в суспензію ще вводять один 3 компонентів: танін 20-30 кг. м ${ }^{3}$; діохромат калій (натрій) 0,5-1,0; кальциновану соду 1,5-2,5; азотистокислий натрій 2,0-10,0";

3 практики видно низьку антикорозійну ефективність компонентів. Після очистки дуже швидко проходить реакція між "голим" металом + кисень + вода і утворюється іржа. Тому необхідно заблокувати центри глибинної корозії в раковинах металу.

При використанні струменевого очищення металевих конструкцій у кварцовому піску знаходиться набагато більше $1 \%$ вільного кремнезему, зазвичай 80-90\%. У процесі струменевої обробки поверхні зерна піску розщеплюються на дуже дрібні мікро-частинки. Ці частинки, розміром менше 5-10 мікрон (E) і майже невидимі, часто ще дуже довгий час залишаються в навколишньому повітрі і вдихаются робітниками і всіма, хто знаходиться поблизу місця проведення очисних робіт. Накопичуючись і затвердіваючи в легенях, викликають пошкодження легеневої тканини, що в свою чергу веде до появи респіраторних проблем. Подібний стан може перейти в силікоз (також відомий, як "хвороба запорошених легень"), хвороба, яка може завершитися фатальним результатом. Тому в багатьох країнах світу піскоструменева обробка заборонена законом.

- пункт 3.9.3: Травлення. В залежності від групи металевих виробів $(1,2,3)$ залежить стан розчинів для травлення, в який входять: сірчана кислота, соляна кислота, інгібітор (катанін, ПБ-6, ХОСП-10), хлористий натрій, ортофосфорна кислота, азотна кислота, хлористе залізо, уротропін, формалін та інші високо небезпечні сполуки;

- пункт 3.9.3.6: При підготовці поверхні виробів, призначених для умов експлуатації У1, У2, У3, УХЛ4, застосовують грунтівки - перетворювачі іржі для поверхонь зі ступенем окислення "А" при неможливості застосування струменево-абразивної очистки або інших методів, що забезпечує більш високу довговічність покриття.

Але ж при цьому ГОСТ 9.402-80 вказує на те, що застосований перетворювач іржі - грунт не повинен шкодити металевій поверхні. Якщо агресивну кислоту нанести на металеву поверхню і не змити іiі після реакції, то такий перетворювач іржі розчинить не тільки іржу, а і нанесе велику шкоду металевій конструкції, навколишньому середовищу і здоров'ю людини.

Діючі стандарти не передбачають застосування танінних модифікаторів іржі в процесі підготовки поверхні під покриття.

Були підготовані матеріали на розроблення ISO "Підготовка сталевих поверхонь під консервування, міжопераційне грунтування, фарбування, обшивку, ізоляцію, герметизацію, бетонування та інші покриття за допомогою танінного перетворювача іржі "CONTRRUST", а також згідно з ДСТУ БВ.2.7.-7798 "Мастики герметизуючі бутилкаучукові"(у співавторстві Баглай А.П.Чернішов В.М., Гутніченко Т.П., Савенко В.І. та ін.) та ДБН В.2.6-22-2001 "Улаштування покриттів із застосуванням сухих будівельних сумішей".(у співавторстві Шейніч Л.О. Савенко В.І. та ін.).

Розроблено наукові засади, методологію, ДСТУ 4372:2005 "Перетворювачі іржі на основі деревинної речовини", чинний від 2006-04-01(додаток ВСТУП), в основу якого закладено патент №61544 та нормативну базу для забезпечення антикорозійного захисту металевих елементів та конструкцій ефективними екологічно безпечними засобами.

Проведено наукові дослідження особливостей експлуатації захисних покриттів. Створено комплекс нових протикорозійних та ізоляційних матеріалів, інноваційних технологій і технологічних процесів підготовки поверхні та нанесення покриттів, методів контролю та діагностики протикорозійного захисту, технологій, методик і технічних засобів з підвищенням надійності експлуатації протикорозійного захисту об'єктів, впровадження яких забезпечує підвищення терміну безаварійної роботи, зниження затрат на ремонтно-відновлювальні роботи, продовження строку експлуатації лакофарбових та ізоляційних покриттів та будівель.

Застосуванням перетворювача іржі "CONTRRUST" забезпечується високоякісна підготовка поверхні до завершальних робіт (застосовується в будьяку пору року для обробки сталевих труб, кабельного оплетення, дахів, арматурної сітки в бетон, вузлів сполучення, під сендвіч-панелі, ємностей, резервуарів, магістральних трубопроводів перед встановленням підсилювальних елементів, металевих конструкцій у шахтах, на електростанціях, на АЕС, в автосервісі, у судноремонті й суднобудуванні (баластні танки, трюми), вагоноремонті, метрополітені, на устаткуванні харчової промисловості, яке неможливо захистити від пилу, піску, іржі, при виробництві особливо чистих вибухових речовин і медичних препаратів, на металоконструкціях, призначених для експлуатації контрольно-вимірювальних приладів, для виявлення гнізд корозії в балонах високого тиску й конструкціях зі спеціальних виробів, зокрема з нержавіючої сталі, а також мікротріщин і поверхневих раковин під час виготовлення сталевих матеріалів спеціального призначення, хімічної, вугільної, нафтогазової промисловості, на об'єктах військових підприємств, на металевих конструкціях, де конструктивно використовуються накладні деталі 3 перери- 
вчастими зварними швами, тобто в місцях, де між з'єднаними деталями утворюються мікротріщини, у яких швидкість корозії в десятки разів більше, ніж на відкритій поверхні, при хімзахисті, вогнезахисті несучих металоконструкцій, на газопроводах без зупинки (додаток ДБН ін-т електрозварювання ім. С.О. Патона) та в інших галузях).

Перш ніж приступити до підготовки поверхні, потрібно:

- обстежити об'єкт;

- провести дефектоскопію на предмет товщини поверхні, не зруйнованої іржею;

- i згідно 3 проектно-кошторисною документацією та інструкцією виробника, під авторським наглядом, нанести перетворювач іржі "CONTRRUST".

Перетворювач іржі наносять на іржаву поверхню суцільним рівномірним шаром, без підтьоків будьяким способом (безповітряне розпилення, шприц та ін.). Рекомендується наносити щіткою, при цьому втираючи перетворювач у поверхню.

Якщо товщина іржі понад 150 мкм і після нанесення першого шару перетворювача іржі плями іржі проявляються, треба на уражені місця нанести перетворювач іржі повторно до утворення суцільної блискучої дрібно- або крупнокристалічної антикорозійної темно-синьої плівки-грунту, яка має високу адгезію з покриттями, а після реакції на поверхні і в мікрощілинах та висихання перетворювача (120 хв.) покрити шпаклівкою, герметиком та пофарбувати .

Нові вироби обробляють перетворювачем іржі з метою попередження корозії в порах і на швах металу. Час висихання перетворювача іржі при температурі $+20^{\circ} \mathrm{C}$ складає 120 хвилин. Якщо він висихає менш, ніж за 120 хвилин, необхідно зволожувати поверхню водою шляхом напилювання або розбризкування. Якщо висихання відбувається більш, ніж за 120 хвилин, допускається сушіння теплим повітрям (обдуванням) або нанесення перетворювача іржі на розігріту поверхню.

Нанесення перетворювача іржі в теплому вигляді підвищує дифузійні властивості (змішування води і компонентів, втирання і розчеплення продуктів корозії ) у 4 рази.

При нанесенні перетворювача іржі на відкритому повітрі необхідно уникати попадання опадів (туман, дощ, сніг) на поверхню до повного висихання перетворювача іржі.

На сталеві конструкції, які є постійно під впливом конденсату, перетворювач іржі наносять також способами, описаними вище. Для таких конструкцій з метою одержання гарної адгезії рекомендується надалі застосовувати покриття, які можуть наноситися на вологу поверхню, наприклад, гліфталеві фарби.

Універсальний перетворювач іржі відноситься до композицій, які наносяться на іржу й не змиваються. Не потрібна утилізація відходів як при його виробництві, так і при застосуванні.

Перетворювач іржі при його застосуванні утворює плівку товщиною $30-50$ мкм і має такі експлуатаційні властивості:

- він заміняє ступінь механічного очищення прокородованої поверхні до стану SA 2,5 за стандартом ISO 8501-1 і забезпечує один шар грунту;

- його перетворююча здатність при середній товщині іржі 300 мкм становить 100\%;

- він не токсичний і не пожежонебезпечний;

- стійкість плівки при $200^{\circ} \mathrm{C}$ до впливу води становить 72 години, трансформаторного масла - 96 годин, нафти-сирцю - 96 годин;

- проникнення через плівку газів під землею не спостерігається;

- відшаровування плівки під землею під впливом блукаючих струмів до 1,2 вольт і при тиску 200 кгс/ см $^{2}$ не спостерігається;

- міцність плівки при ударі не менша 4 Дж; 2 бали;

- адгезія плівки до лакофарбових покриттів 1-

- при рН 0,5 - 2,2 моль/л утворена плівкагрунт не викликає кислотної корозії при експлуатації, так як кислотність нейтралізується при взаємодії компонентів з продуктами корозії і тонатами.

Ці й інші властивості модифікатора іржі забезпечують його технічну й економічну ефективність .

При необхідності, шпателем наноситься двокомпонентна шпаклівка (склад шпаклівки: поліефірна смола, цемент, пісок, перетворювач іржі "КОНТРАСТ" модифікація "В", затверджувач типу гіпарис) в щілини та вм'ятини протягом 30 хвилин і залишається для затвердіння на 24 години (автор Смик Л.П.).

Перспективними для використання в антикорозійному захисті є модифіковані покриви холодного нанесення на основі водних бітумних емульсій бітумно-латексні емульсії [1]. Матеріалами для модифікації бітумів і бітумних емульсій та отримання на їх основі емульсій з покращеними властивостями є латекси 3 додаванням модифікатора іржі "КОНТРАСТ" модифікації "В" можуть використовуватись мастики герметизуючі бутилкаучукові згідно з ДСТУ Б.В.2.7 - $77-98$ або для захисту арматури та закладних і накладних деталей сухих сумішей згідно з ДБН В 2.6 - 222001 "Улаштування покриттів із застосуванням сухих будівельних сумішей" під загальною редакцією Лівінського О.М.

Для перевірки впливу рівня та якості підготовки поверхні на захисні властивостивості покривів ї наносили на металеві пластинки 3 низьковуглицевої сталі, поверхні яких було підготовано такими способами: 1) механічна очистка ( $\mathrm{Ra}=10-12$ мкм);2) піскоструменева очистка ( $\mathrm{Ra}=50-75$ мкм; 3$)$ дробоструменева очистка ( $\mathrm{Ra}=125 \mathrm{M \kappa м})$; 4) підготовка поверхні перетворювачем іржі "КОНТРАСТ" модифікації А". На рис. 1 наведено зовнішній вигляд даних поверхонь.
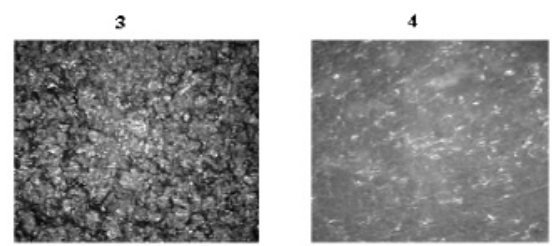

Рис. 1. 
Таблиця 1. Результати випробувань адгезії покриву до сталі при різних способах підготовки поверхні

\begin{tabular}{|l|l|c|c|c|c|c|}
\hline \multirow{2}{*}{\begin{tabular}{c}
\multirow{2}{*}{ № } \\
пор.
\end{tabular}} & \multirow{2}{*}{ Спосіб підготовки поверхні } & \multicolumn{5}{|c|}{ Адгезія до сталі, Ра } \\
\cline { 3 - 7 } & & $3 \%$ & $5 \%$ & $7 \%$ & $10 \%$ & $15 \%$ \\
\cline { 3 - 7 } & Механічна очистка & 1,8 & 2,8 & 1,8 & 1,6 & 1,7 \\
\hline 2 & Піскоструменева очистка & 1,9 & 2,9 & 1,8 & 1,6 & 1,7 \\
\hline 3 & Дробоструменева очистка & 1,9 & 2,8 & 1,8 & 1,6 & 1,7 \\
\hline 4 & $\begin{array}{l}\text { Перетворювач іржі «КОНТРАСТ» } \\
\text { модифікація «А» }\end{array}$ & 1,7 & 2,9 & 1,7 & 1,5 & 1,6 \\
\hline
\end{tabular}

Однією із найважливіших фізико-механічних властивостей покривів для протикорозійного захисту є адгезія покриву до основи, яку ми обрали за критерій оцінки впливу рівня та якості підготовки поверхні на захисні властивості систем покривів. Дослідження показали приблизно однакові результати, тобто нанесення покриву не вимагає ретельної підготовки поверхні. Результати випробувань адгезії покриву до сталі при різних способах підготовки поверхні наведено у табл. 1.

Проаналізувавши отримані результати, для подальшої роботи обрано покрив, що містить 7\% латексу стирол-бутадієнового синтетичного каучуку та розроблено 3 системи покривів на основі водних бітумно-латексних емульсій для протикорозійного захисту,емульсії на основі полістирольного лаку і т.д. Наприклад, система захисту трубопроводів. Їх наведено на рис. 2.

Призначенням протикорозійного покриття (або системи покриттів) є недопущення контакту агресивних грунтів із сталевою поверхнею трубопроводу або іншого металевого виробу та попередження утворення джерел корозії.

На підготовлену поверхню перетворювачем іржі "КОНТРАСТ" можуть бути нанесені різні покриття. Економічний ефект від застосування перетворювача іржі "КОНТРАСТ" визначається індивідуально до об'єкту. "КОНТРАСТ" впроваджено на багатьох об'єктах в різних організаціях і країнах. Загальний економічний ефект від його впровадження складає понад 60 млн. грн. на об'єктах в Україні, в тому числі таких, як "Карпатнафтохім", Українська стрічкова фабрика, "Плавзасоби України", ВАТ "ДБК-3", ПАТ "ДБК-4" та багатьох інших.

Аналіз результатів випробувань показав, що в зразках з гладкою арматурою відбулось висмикування арматурних стержнів з бетонної призми. Середнє значення сили, при якій відбулось висмикування арматурних стержнів, для зразків з необробленою та обробленою антикорозійним засобом "Contrrust" відповідно становила 23,38 кН та 23,39 кН. У зразках з ребристою арматурою відбулось руйнування бетонних призм (розколювання на дві частини). Середне значення сили, при якій відбулось розколювання бетонних призм, для зразків з необробленою та обробленою антикорозійним засобом "Contrrust" відповідно становила 29,88 кН та 30,08 кН.

$\mathrm{y}$ результаті виконаних випробовувань встановлено, що обробка арматурних стержнів антикорозійним засобом "Contrrust" не погіршує зчеплення арматури $з$ бетон

\section{Висновки}

1. Фізико-механічні властивості консерванта перетворювача іржі "КОНТРАСТ" та покриттів на основі водної бітумно-латексної емульсії, бутилкаучукових мастик, сухих будівельних сумішей та ін..дозволяють перетворити іржу ( навіть шілинну і у важкодоступних місцях) в хелатні метало полімери , які надійно блокують міця корозії і під фарбовими покриттями корозія металу не відбувається.

2. Досліджено вплив рівня та якості підготовки поверхні на захисні властивості покриттів. Результа-
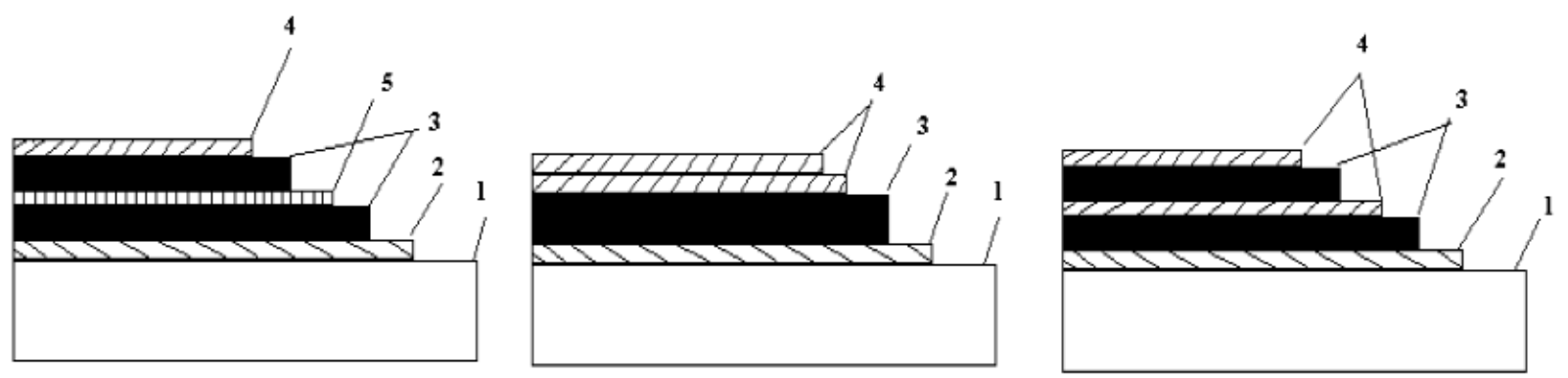

Рис. 2. Конструкції систем покриттів:

1 -сталева основа; 2- грунт "КОНТРАСТ", 3 - покриття бутилкаучуковою герметизуючою мастикою або спеціальним покриттям при потребі; 4 - армувальна сітка згідно з ДСТУ БВ.2.7.-77-98 "Мастики герметизучі бутилкаучукові" (в співавторстві Баглай А.П., Савенко В.І., Гутніченко Т.П. та ін..) або ДБН В.2.6 - $22-2001$ Улаштування покриттів із застосуванн Рисунок. 2. Конструкції систем покриттів: 1 -сталева основа; 2- грунт "КОНТРАСТ", 3 - покриття бутилкаучуковою герметизуючою мастикою або спеціальним покриттям при потребі; 4 - армувальна сітка згідно з ДСТУ БВ.2.7.-77-98 "Мастики герметизучі бутилкаучукові" (в співавторстві Баглай А.П., Савенко В.І., Гутніченко Т.П. та ін..) або ДБН В.2.6 22 - 2001 Улаштування покриттів із застосуванням сухих будівельних сумішей (в співавторстві Шейніч Л.О., Савенко B.I. та ін..) з відповідним герметиком і фарбуванням 5-фарбуванняям сухих будівельних сумішей (в співавторстві Шейніч Л.О., Савенко В.І. та ін..) з відповідним герметиком і фарбуванням 5-фарбування 


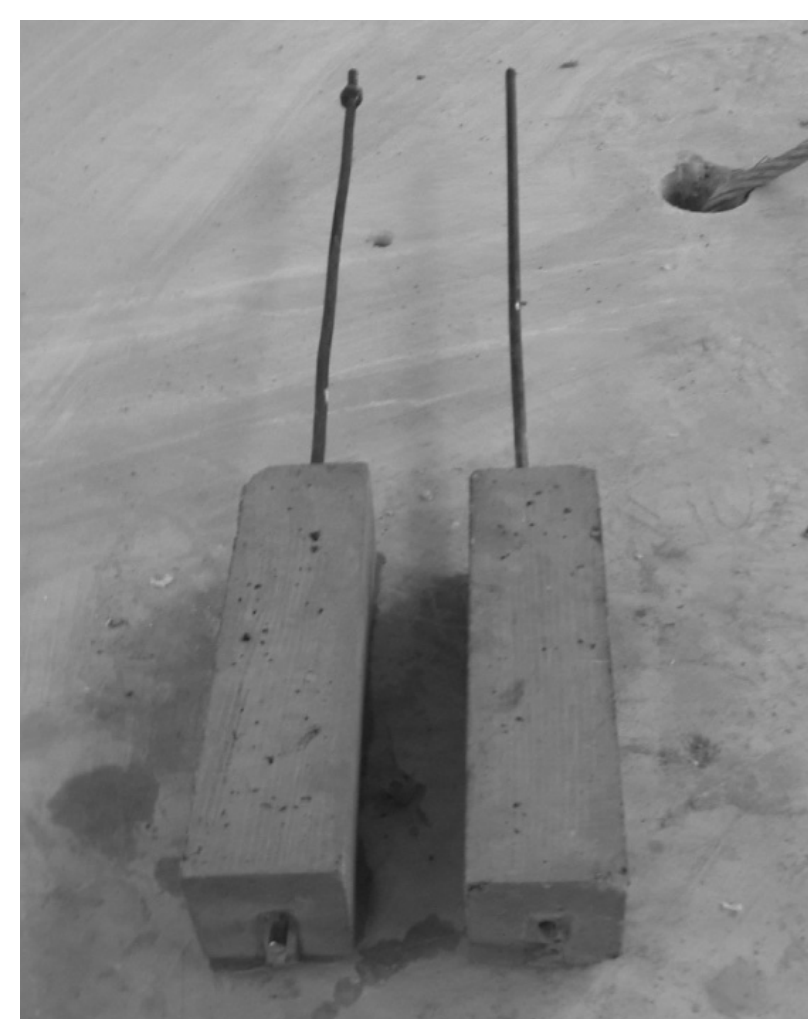

Фото 2. Дослідні зразки з гладкою арматурою до випробування (з ліва) та після випробування (з права)

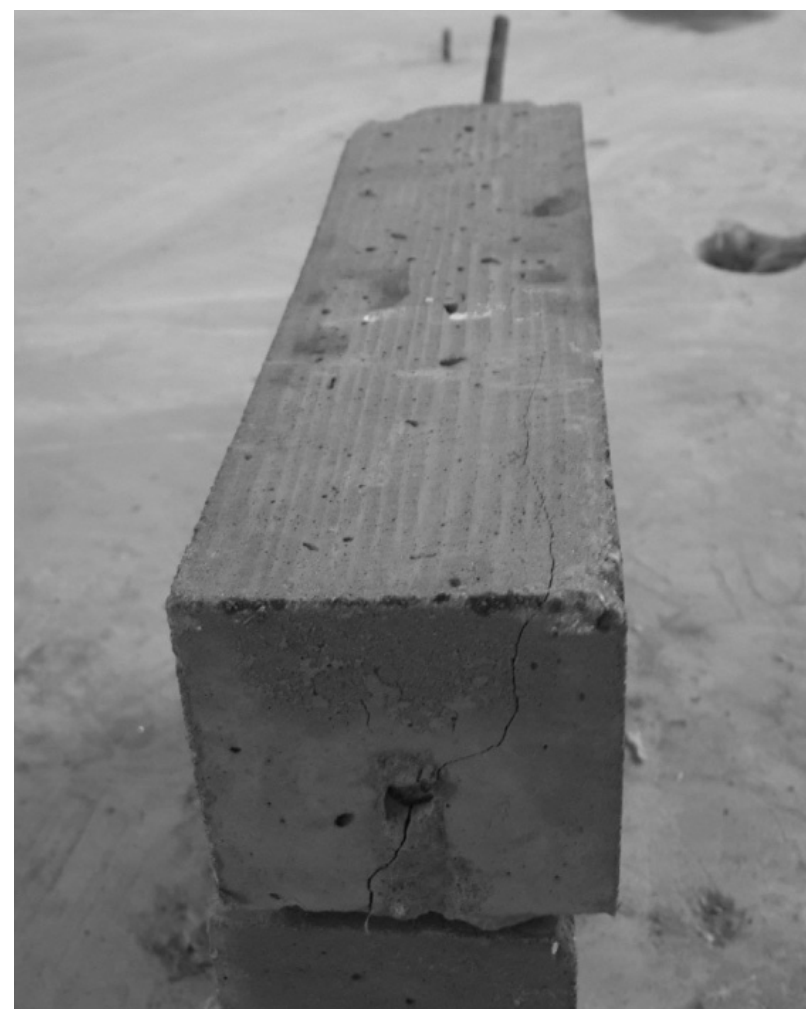

Фото 4. Дослідний зразок з ребристою арматурою після випробування

ти дослідження вказують на те, що покриття на основі бітумно-латексних емульсій бутилкаучукових мастик та сухих сумішей розробленого складу не потребують трудомісткої технологічно складної ретельної підготовки поверхні перед нанесенням.

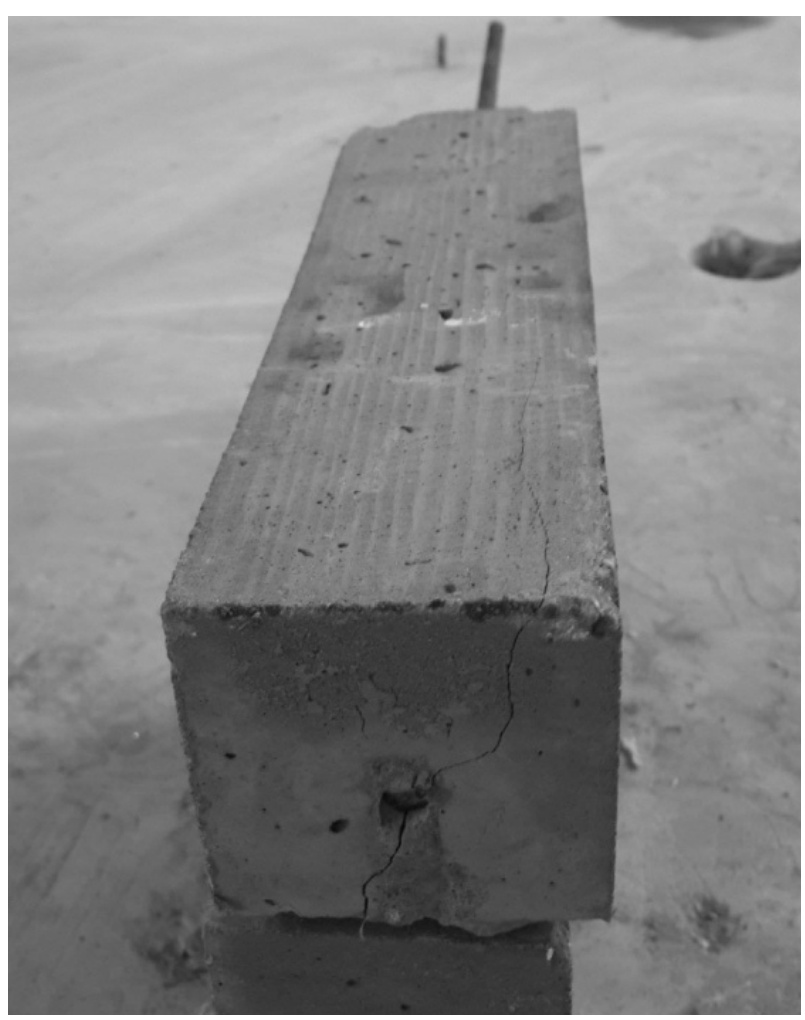

Фото 3. Дослідний зразок з гладкою арматурою після випробування

3. Проведені дослідження та випробування довели, що запропоновані конструкції систем покриттів відповідають необхідним нормативним вимогам для забезпечення антикорозійного захисту нафтогазопроводів, машин та інших металовиробів i можуть мати великі перспективи, в першу чергу, для ремонту вже існуючих об'єктів.

4. Проведені дослідження в лабораторіях КНУБА та ЛНТУ показали, що у арматури, обробленої модифікатором КОНТРРАСТ зчеплення 3 бетоном в залізобетонних конструкціях не погіршується. Це дає можливість в разі необхідності ( в підземних спорудах, у воді , в агресивному середовищі і т.д.) захищати арматуру , закладні та накладні деталі, труби , корпуси резервуарів тошо від корозії.

5. Загальний економічний ефект від впровадження роботи складає понад 60 млн. грн. (додаток 8) в тому числі: м. Київ, вул. Солом'янська 2а, замовник апеляційний суд, проектант - ЗАТ "ГІПРОцивільпромбуд" -економічний ефект - 30,0 млн.грн.; ПАТ "ПВІ-ЗІТ Нафтогазізоляція" як виконавець на газопроводах Кутаісі-Абаша (Грузія) - 10,2 млн. грн., Львів- Бобрівка - 0,743 млн. грн., Брест (Білорусія) - 0,739 млн.грн; Кампанія "Лукойл" - "Карпатнафтохім" - 6,41 млн.грн; Харків, Сумський ринок - виконавець ТОВ "Спецбудмонтаж - Україна" - 5,8 млн.грн; Храм, м.Київ, вул.Мічуріна $64-981$ тис.грн., об'єкти оборонного комплексу України, в тч. Житомирський БТЗ, Шепетівській Р3, Миколаївський БЗ, та інші. 


\footnotetext{
Jimepamypa

1. Ковалець С.І. Метали та їх властивості / С.І. Ковалець. - К., 1983. - 126 c.

2. Хомченко Г.П.,Цитович И.Г. Неорганическая химия / Г.П. Хомченко, И.Г. Цитович. - М.: Высшая школа, 1987. $464 \mathrm{c}$.

3. Фримантл М. Химия в действии:. В 2-х ч. -ч.1. / М. Фримантл - М.: Мир, 1998. - 528 с.

4. ТУУ 14333-082/001-98 "Перетворювач іржі "КОНТРАСТ" - К., 1998

5. ДСТУ 4372:2005 "Перетворювач іржі на основі деревинної речовини. Технічні вимоги." - К., 2005

6. Патент № (11) 61544 "Перетворювач іржі "КОНТРАСТ"

7. Техника борьбы с коррозией: Пер. с пол. / Р. Юхневич, В. Богданович, Е. Валашковский и др.; под ред. А.М. Сухотина. - Л.: Химия, 1980. - 224 c.

8. Розенфельд И. Л. Защита металлов от коррозии лакокрасочными покрытиями / И. Л. Розенфельд, Ф. И. Рубинштейн, К. А. Жигалова. - М.: Химия, 1987. - 222 с.

9. Петров Л. Н. Коррозионно-механическое разрушение металлов и сплавов / Л.Н. Петров. - К.: Наук. думка, 1991. $215 \mathrm{c}$.

10. Шлугер М. А. Коррозия и защита металлов: учеб. пособие для вузов / М. А. Шлугер, Ф. Ф. Ажогин, Е. А. Ефимов. - М.: Металлургия, 1981. - 215 c.
}

\title{
References
}

1. Kovalec SI Metals and their properties / SI Kovalec - K., 1983. - $126 \mathrm{p}$.

2. Khomchenko GP, Tsitovich IG Inorganic chemistry / gp Khomchenko, IG Tsitovich - M .: Higher school, 1987 - 464 pp.

3. Fremantle M. Chemistry in action :. In 2 hours.-1. / M Fremantle - M .: World, 1998. - 528 pp.

4. TUU 14333-082 / 001-98 "Rust Converter" CONTRAST "- K., 1998

5. DSTU 4372: 2005 "Rust converter on the basis of wood material. Technical requirements. "- K., 2005

6. Patent № (11) 61544 "Rust Converter" CONTRAST"

7.Techhnika fight against corrosion: Per. from the floor / R. Yukhnevich, V. Bogdanovich, E. Valashkovsky and others; ed. AM Sukhotina - L.: Chemistry, 1980. - 224 pp.

8. Rosenfeld IL Protection of metals from corrosion by varnish coatings / I. L. Rozenfeld, F. I. Rubinshtein, K. A. Zhigalov. Moscow: Chemistry, 1987. - 222 p.

9. Petrov L. N. Corrosion-mechanical destruction of metals and alloys / L.N. Petrov - K .: Science. opinion, 1991. - 215 p.

10. Schluer MA Corrosion and metal protection: study. allowance for high schools / MA Shluger, FF Azhogin, EA A. Efimov. Moscow: Metallurgy, 1981. - $215 p$.

\section{В.И. Савенко, Л.М. Висоцкая, Д.Я. Кислюк, В.В. Клюева, С.В. Федоренко, С.П. Пальчик}

\section{ЭКОНОМИЧЕСКАЯ ЦЕЛЕСООБРАЗНОСТЬ ПРОДЛЕНИЯ СРОКА ЭКСПЛУАТАЦИИ МЕТАЛЛИЧЕСКИХ КОНСТРУКЦИЙ, МАШИН И ИЗДЕЛИЙ ПУТЕМ ЗАЩИТЫ ОТ КОРРОЗИИ ЭКОЛОГИЧЕСКИ ЧИСТЫЕ СРЕДСТВА (CONTRRUST)}

\begin{abstract}
Аннотация. Коррозия приводит к миллиардным убыткам ежегодно, которые заключаются в выводе из строя изделий и машин из металла, а также в издержках по защите и восстановлению металлических изделий. Исследование процессов коррозии дает основу утверждать, что надежная защита от коррозии - это в первую очередь правильная подготовка поверхности и только потом качественный слой герметиков, красок или других типов покрытия.

Экологически чистое вещество растительного происхождения, запатентована и испьтана, под названием "KOHTPACT (CONTRRUST)" является эффективным средством блокировки источников коррозии (ржавления) и подготовки поверхностей к защитным покрытиям.

Ключевые слова: КОНТРАСТ, коррозия, ржавчина, покрытия, экология.
\end{abstract}

V.I. Savenko, L.M. Vysotskaya, D.Ya. Kislyuk, V.V. Klyuev, S.V. Fedorenko, S.P. Palchik

\section{ECONOMIC EXPEDIENCY OF EXTENSION OF TERMS OF USING OF METAL CONSTRUC- TIONS, MACHINES AND PRODUCTS BY PROTECTION FROM COROSSION WITH ENVIRO- MENTALLY FRIENDLY PRODUCTS (CONTRRUST)}

\begin{abstract}
Corrosion leads to billions of losses each year, consisting in putting down articles and machines made of metal, as well as the costs for the protection and restoration of metal products. Investigation of corrosion provides a basis to assert that the corrosion protection - is primarily a correct surface preparation and then a layer of high-quality sealants, paints or other types of coverage.

Environmentally friendly plant substance, patented and tested, with the name "CONTRRUST" is an effective means of blocking sources of corrosion (rust) and surface preparation for protective coatings.

Keywords: CONTRRUST, corrosion, rust, protective coatings, ecology.
\end{abstract}

